\title{
Relevance, Rigor, and Relationships: Student Perceptions Following Participation in an Integrated Experiential Zoo-Based Academic High School Science Program
}

\author{
Elizabeth A. Mulkerrin ${ }^{1}$, John W. Hill ${ }^{2}$ \\ ${ }^{1}$ Henry Doorly Zoo, Omaha, USA \\ ${ }^{2}$ University of Nebraska at Omaha, Omaha, USA \\ Email: jhill@unomaha.edu
}

Received February $26^{\text {th }}, 2013$; revised March $28^{\text {th }}, 2013$; accepted April $10^{\text {th }}, 2013$

\begin{abstract}
Copyright (C) 2013 Elizabeth A. Mulkerrin, John W. Hill. This is an open access article distributed under the Creative Commons Attribution License, which permits unrestricted use, distribution, and reproduction in any medium, provided the original work is properly cited.
\end{abstract}

\begin{abstract}
The purpose of this survey study was to compare students' measured Likert scale perceptions of posttest school climate survey, relevance, rigor, and relationships domain scores following 11th- and 12th-grade participation in either an integrated experiential zoo-based academic high school science program $(n=18)$ or a same school district integrated experiential school-based academic high school science program $(n=$ 18 ). Science coursework delivery site served as the study's independent variable. ACT composite scores and science grade point average scores were equivalent for students participating in both science programs. Students participating in the zoo-based experiential academic high school science program completed real world, hands-on projects on-site at a nationally recognized zoo while same school district control group students participating in the integrated experiential school-based academic high school science program completed matched curriculum, real world, simulated projects in their classrooms. Students who completed the integrated experiential zoo-based academic high school science program compared to control group students had statistically greater posttest Likert scale perceptions of program relevance where independent $t(34)=4.13, p=.0002$ (two-tailed), $\mathrm{ES}=1.410$; program rigor $t(34)=3.66, p=.0008$ (two-tailed), $\mathrm{ES}=1.237$; and program relationships $t(34)=4.98, p<.0001$ (two-tailed), $\mathrm{ES}=1.690$. The importance of these powerfully held beliefs for students' successful participation in their future science studies is discussed.
\end{abstract}

Keywords: Zoo-Based; Experiential; High School Science Program; Relevance; Rigor; Relationships

\section{Introduction}

America's students are neither mastering nor are they being adequately taught science and mathematics content as demonstrated by their Third International Mathematics and Science Study (TIMSS) scores, National Assessment of Educational Programs (NAEP) scores, or Program for International Student Assessment (PISA) test scores (Conley, 2001; Gonzales, Williams, Jocelyn, Roey, Kastberg, \& Brenwald, 2008; Grigg, Lauko, \& Brockway, 2006; Mourshed, Chijioke, \& Barber, 2010; Peterson, 2010; Pittman, 2005) which ranks them average compared to students from other participating countries. International and national assessments are designed to test mastery of content, knowledge, reasoning, and understanding of science and mathematics at grades four, eight, and eleven (Gonzales et al., 2008; Grigg et al., 2006; Mourshed et al., 2010; Sawchuk, 2010). It has been asserted that students' average scores on these high stakes assessments are unfortunate predictors of why the United States may be falling behind in its competitive edge in math and science careers-made all the more poignant when the goal is for America's students to score and be ranked in the top five globally (National Academies, 2007; Peterson, 2010).

\section{TIMSS Achievement Scores}

Of significant concern to educators, policy makers, and politicians alike is that TIMSS math achievement test scores trend lower over time as students are evaluated in the fourth-grade and eighth-grade. For example, in the most recent TIMSS (2007) math report, students in the fourth-grade scored 11th out of 36 countries with an average score of 529, and students in the eighth-grade scored 9th out of 48 countries on math with an average score of 508. Furthermore, both males and females at all evaluated grade levels scored within the intermediate level of math knowledge where male students' scores were marginally higher than female students' math scores. For example, fourth-grade males on average scored 532, which is 32 points above the average TIMSS scale of 500 where fourth-grade females on average scored 526, which is 26 points above the average TIMSS scale of 500. Eighth-grade males on average scored 510 , which is 10 points above the average TIMSS scale of 500 where eighth-grade females on average scored 507, which is 7 points above the average TIMSS scale of 500 .

The math TIMSS results for fourth-grade students' show how both males and females on average are scoring at the intermediate level of the international benchmark, and only $10 \%$ 
are scoring at or above the advanced international benchmark level. The TIMSS results for eighth-grade students show a similar picture, where both males and females on average are scoring at the intermediate level of the international benchmark, and only $6 \%$ are scoring at or above the international benchmark advance level (Gonzales et al., 2008; Peterson, 2010). When comparing the math results of US students to other countries, in both cases, seven countries had a higher percentage of students at or above advanced international benchmark level. The results show US students are not mastering mathematical content and are falling further behind as they progress through the educational system.

\section{Science Achievement}

Of even greater concern to educators, policy makers, and politicians is that TIMSS science achievement test scores also follow the math achievement scores and trend lower over time as students are evaluated in the fourth-grade and eighth-grade. For example, in the most recent TIMSS (2007) science report, students in the fourth-grade scored 8th out of 36 countries with an average score of 539, and students in the eighth- grade scored 11 th out of 48 countries on science with an average score of 520. Furthermore, both males and females at all evaluated grade levels scored within the intermediate level of science knowledge where male students' scores were marginally higher than female students' science scores. For example, fourth-grade males on average scored 541, which is 41 points above the average TIMSS scale of 500 where fourth-grade females on average scored 536, which is 36 points above the average TIMSS scale of 500. Eighth-grade males on average scored 526, which is 26 points above the average TIMSS scale of 500 where eighth-grade females on average scored 514, which is 14 points above the average TIMSS scale of 500 .

The science TIMSS results for fourth-grade students show both males and females on average are scoring at the intermediate level of the international benchmark and only $15 \%$ of US fourth-graders are scoring at or above the advance international bench mark level. The TIMSS results for eighth-grade students show both males and females on average are scoring at the intermediate level of the international benchmark and only $10 \%$ of US eighth-graders are scoring at or above the advance international benchmark level (Gonzales et al., 2008; Peterson, 2010). The science test results indicate US students are not mastering science content and are falling behind students from other nations at all grade levels.

The TIMSS assessment is one of many indicators demonstrating how our students are either not mastering math and science curriculum or are not receiving a level of math and science instruction and activities sufficient to raise their knowledge base and therefore test scores. The apparent trend extent in international and national assessments is the fact that as our students progress through the US education system they fare worse on these assessments over time. Instead of our students moving ahead in math and science by the time they are in the 12th-grade, they lag behind students from many countries with fewer advantages and opportunities for learning. Moreover, decreasing math and science National Assessment of Educational Programs (NAEP) assessment scores are observed through high school. For example, by the time students have completed the 11th-grade, their science NAEP (2009) test scores on average have decreased 13 percentage points compared to their fourth- grade scores. The same holds true in math scores where by the time students have completed the 11th-grade, their math NAEP (2009) test scores on average have decreased 13 percentage points compared to their fourth-grade scores (National Center for Education, 2011a, 2011b, \& 2011c). Alarming trends like the decrease of math and science proficiency in content knowledge from fourth-grade to the 12th-grade sends a message that the US educational system needs to find a solution to the problem so our country can keep its competitive edge in math and science careers.

\section{Seeking Math and Science Education Reform}

Recent education reforms call for addressing the math and science instructional needs of high school students in order to better prepare them for math and science examinations as well as true success in and beyond the classroom (Achieve, Inc., 2009; Silverstein, Dubner, Miller, Glied, \& Loike, 2009). For example, academy reform models are designing specialized programs and schools that focus on the rigor and relevance of math and science curriculum where students are completing their core curricular courses during their freshman and sophomore years and opening up science and math electives and unique opportunities for students to explore a variety of career pathways (Achieve, Inc., 2005). It is theorized that creating an educational environment that has a balanced and rigorous curriculum while providing experiential learning in real-world relationship driven science and math environments will better prepare students to be competitive in today's global work force which demands these skills (Achieve, Inc., 2009; Kemple, 2004; Kemple \& Willner, 2008; Pittman, 2005).

\section{Review of Literature}

Recent findings of how students in the United States rank on international math and science exams suggest that our students, while receiving a breadth of content knowledge, may not be receiving the depth of knowledge they need to keep a competitive edge in math and science careers (Bybee, 2010; Grigg et al. 2006; Mourshed et al., 2010; Sawchuk, 2010). The main, educational systems throughout the country are working to develop programs that will inspire students to be innovative, creative, active learners able to think critically and envision a future filled with success and service to others (Bybee, 2010).

To better prepare our students for success in the global economy, several innovative high school reforms have been established to increase the number of students who graduate and successfully transition into postsecondary education or the global work force (Achieve, Inc., 2005; Kemple, 2004; Kemple \& Willner, 2008; Quint, 2006). For over a decade, educators have seen the impact of school reform changes in high schools across the country decrease the number of students dropping out, improving school climate, strengthening curriculum and instruction, decreasing the achievement gap between majority and minority students, and preparing students for transition to postsecondary programs or employment after graduation (Kemple, 2004; Kemple \& Willner, 2008; Quint, 2006).

The goal of high school has changed from only preparing a few students for postsecondary education to preparing all students for living successfully in an interdependent world (Conley, 2001; Pittman, 2005). To prepare students with 21st century skills needed to be both college and career ready, high schools are creating educational environments filled with rigor, 
relevance, and relationships; these conditions are needed to ensure that all students may be economically and personally successful (Achieve, Inc., 2009; Conley, 2001; Hawkins, Oesterle, \& Hill, 2004; Johnson \& McElroy, 2010; Manning \& Saddlemire, 1996; Quint, 2006). In order to ensure rigor, relevance, and relationships, school goals now clearly focus on components of change capacity such as improved school climate, a strengthened curriculum, hands-on active experiential learning opportunities, and personalized relationships (Breunlin, Mann, Kelly, Cimmarusti, Dunne, \& Lieber, 2005; Dryer, 1996; Toch, Jerald, \& Dillon, 2007). Thus, developing student competencies, skills, and social behaviors are all thought to be beneficial to self and society (Hawkins et al., 2004).

Nationally, the trend in science education is to move away from general to more in-depth content knowledge. Leaders in science education are creating standards, guidelines, and assessments to prepare our students to become more competitive globally. The National Science Education Standards (NSES) were established in 1996 to be used as guidelines by educators to create rigorous and relevant curriculum that will be used to improve our students' understanding of and ability to master science and math concepts (National Research Council, 1996). Instead of United States educators utilizing standards and assessments as guidelines and tools to determine the mastery of science and math in our students, they are using standards to create prescriptive curricula and pedagogical methods to ensure consistency in all classrooms and for all students to achieve basic mastery of content knowledge (Sawchuk, 2010). In reality, current science and math learning activities are more likely to reflect local learning goals that not only adhere to NSES standards (1996) but go beyond a prescribed curriculum to a creative curriculum that gives teachers and local schools more latitude over pedagogy and curricula and greater accountability for student content mastery and success (Mourshed et al., 2010; National Academies, 2007; Sawchuk, 2010).

Leaders in science education are demanding school systems to require students to spend more time doing science as the best way to understand science (National Academies, 2007). Taking active learning into account, educators must evaluate how to incorporate more in-depth content rigor into a curriculum that is already overwhelming in its scope and sequence. For example, recommendations by the National Academies of Science Committee, as set forth in their blueprint for science education, Rising Above the Gathering Storm (2007), suggests education systems should establish specialty schools to immerse students in science, technology, and mathematical education as a way to test the relevance and rigor of science curriculum (Mourshed et al., 2010; National Academies, 2007; Sawchuk, 2010). The rich combination of specialty schools and rigorous curriculum that is relevant may create a nation of students who are competitive in today's global market (Achieve Inc., 2009; Conley, 2001; Mourshed et al., 2010; National Academies, 2007; Sawchuk, 2010).

\section{Learning Environment}

Positive learning environments where educators know their students, develop a concern for their wellbeing, and provide a curriculum that is both rigorous and relevant remain the keys to motivating adolescents (Cleary \& English, 2005; Keefe, Kelley, \& Miller, 1985; Quint, 2006). To create positive learning environments, the school and the community must establish a new culture of personalized learning where students feel confident to become effective team players and intellectual decisionmakers (Conley, 2001; Dryer, 1996; Hugh, Taylor, Chin, \& Hutchinson, 2006; Mackin, 1996). To effectively establish positive learning environments within schools is to develop a culture for learning. In order for a school to develop a culture for learning, it must develop new content knowledge and skills, establish small learning communities, have access to new resources, and develop leadership (Dryer, 1996; Fullan, 2006; Manning \& Saddlemire, 1996; Sergiovanni, 1994). Effective science and math learning activities create an environment where teachers can freely guide students through experiential curriculum supported by ready access to professional resources that will place students in environments where they may demonstrate leadership, collaboration, communication, and selfgovernance in real-world situations (Hugh et al., 2006).

Finally, the business community must come together with the school to complete the new culture of learning needed to raise academic standards and connect students to their lives outside of school (Toch et al., 2007). Together, business leaders and educators must develop an understanding of the educational experiences that occur in all community organizations (Senge, Cambron-McCabe, Lucas, Smith, Dutton, \& Kleiner, 2000) and establish alternative learning environments where students can explore careers. Establishing these partnerships will give students the opportunity to learn the necessary workplace skills and knowledge needed to transition between school and work (Hugh et al., 2006). Everyone working together as a community-business leaders, teachers, scientists, and students-are more likely to create successful change that better prepares students for successful transition into global careers (Achieve Inc., 2009; Kemple, 2004; Quint, 2006). Science classrooms often emphasize the kind of collaborative practices found in the workplace. The social learning environments found in science classrooms are very similar to the communities of practice found in science (Hugh et al., 2006).

Creating a sense of community within schools where all students know that they are valued, belong, and can succeed is an essential ingredient of implementing communities of practice found in science environments and brought to life in schools both large and small (Breunlin et al., 2005; Manning \& Saddlemire, 1996). The development of communities in schools gives administrators, teachers, and students the ability to share ideas and leadership roles forming authentic relationships, wanting to better know oneself and community members, and being receptive to new ideas (Cleary \& English, 2005; Sergiovanni, 1994). The basic human need is to belong and feel part of a group that works towards common goals, common interests, shared values, conceptions, and ideas (Graves, 1992; Hugh et al., 2006; Manning \& Saddlemire, 1996; Sergiovanni, 1994).

\section{Small Learning Communities}

The most common reform we see today is implementing small learning communities within high schools, such as the creation of career academies. The philosophy behind small learning communities, schools-within-schools, or career academies is to develop relationships between the students and teachers, increase rigor, and increase relevance (Cleary \& English, 2005; Conley, 2001). Rigor, relevance, and relationships reform efforts focus on raising academic standards, connecting student studies to their lives outside of school, and preparing students for the ever-changing global workforce. Research shows students who participate in small learning communities 
feel more accepted and part of the school culture. Students who feel they belong and are safe are likely to succeed academically and move into postsecondary degree programs or professions (Conley, 2001; Dryer, 1996).

The rational for establishing small learning communities is to satisfy the basic human need to feel part of a group that works towards a common goal, common interests, shared values, and ideas, for schools and classrooms to be interdependent, cooperative communities where students and teachers learn and work in more comfortable and inspiring environments (Cleary \& English, 2005; Dryer, 1996; Graves, 1992; Manning \& Saddlemire, 1996; Sergiovanni, 1994). The development of communities in schools give administrators, teachers and students the ability to share ideas and leadership roles forming authentic relationships, wanting to better know oneself and community members, and being receptive to new ideas (Dryer, 1996; Keefe et al., 1985; Sergiovanni, 1994). School programs that emphasize small learning communities develop personalized environments where student-teacher relationships develop to increase the academic and social needs of the students (Adelman \& Taylor, 2009; Breunlin et al., 2005; Dryer, 1996).

Small learning communities take on several different formats in high schools across the country. When establishing small learning communities, school leaders need to make sure professional learning communities are established where the focus is on what will successfully support every student in their high school experience, provide every student with meaningful adult relationships, and insure a personalized learning experience where students are able to see the relevance in their learning task (Cleary \& English, 2005; National Association of Secondary School Principals, 2005). It is very important that these key points are well established in order for the school climate to become successful.

Small learning communities come in a variety of forms within a high school, such as career academies, theme-based academies, or schools-within-schools. All three types of small learning communities have shown positive educational benefits for the students who they serve (Cleary \& English, 2005; Kemple, 2004; Quint, 2008).

The talent development small learning communities' model is made up of the positive components seen in learning communities around the country. This model provides a personalized and orderly learning environment, assists students who enter with poor academic skills, improves instructional content and practice through professional learning communities, and prepares students for the world beyond high school (Cleary \& English, 2005; Quint, 2008). The talent development model creates small learning community components starting with a 9th-grade success academy that becomes 10th-grade through 12th-grade career academies (Quint, 2008).

Ninth-graders enter into a success academy where they are guided through the transition into high school, provided the extra academic assistance needed to succeed in high school, and are part of a small community made up of students and educators working together as a family unit (Quint, 2008). Tenthgrade through 12th-grade students are provided with multiple career academies or pathways to keep them engaged through career exploration that creates a linkage to the world they will enter after graduation (Conley, 2001; Hoachlander, 2008). These career academies are community partnerships where students and educators are given the opportunity to work with local professionals to continue to develop integrated problem- based curriculum, critical thinking skills, and communication skills.

\section{Career Academy High School Science Models}

Currently there are over 2500 career academies nationally that are operating as a single program, such as Omaha's Henry Doorly Zoo's Zoo Academy program that operates inclusively on the zoo property (Kemple, 2004; Quint, 2006). Career academies are geared to blend academic rigor, specialized college preparatory curriculum, workplace knowledge, and relevant engaging experience within the workplace (Cleary \& English, 2005; Smith, 2008). Across the nation, career academies have different structures and learning environments. Some academies are housed within the high school, where students take a series of career themed courses. Other academies are located outside of the high school within partnering businesses. These academies provide very authentic learning environments where the school and partnering businesses work together to provide rigorous curriculum and relevant experiences. All career academies have three distinguishing characteristics: 1) develops personalized learning environments through small learning communities; 2) combines the relevance and rigor of academic and career curricula around a career related theme; 3 ) establishes partnerships with local community businesses to provide work-based learning opportunities for students (Hugh et al., 2006; Kemple, 2004; Smith, 2008).

Findings show the rigor incorporated into the career academies demonstrates the feasibility of accomplishing goals of school-to-career without compromising academic goals. Career academy and business partners provide students with a broad array of career awareness and development experiences both in and outside of school including multiple pathways and workbased learning experiences (Hoachlander, 2008; Kemple, 2004; Pittman, 2005; Quint, 2006). The basic model used in career academies is composed of a team of teachers who are linked with a group of students, block scheduling of classes, common planning time for teachers, and an occupational focus. In this model, the teachers, students, and business partners work together as a cohesive group to create a learning environment that provides a safe place for students to explore and experience the relevance of courses through the workplace (Elliott, Hanser, \& Gilroy, 2002).

Career academies provide students with explicit introductions to the world of work and furnish them with skills and connections to help them transition from high school to successful employment (Kemple, 2004). Students commonly believe and feel school is irrelevant to the real world. The intent of career academies is to affiliate career-related education with local businesses so students can see the connection between school and work (Elliott et al., 2002).

\section{Exemplary Zoo Academy High School Models}

Exemplary models of successful zoo academies in the country are Asheboro High School Zoo School, Cabrillo High School Aquarium, Cincinnati Zoo Academy, Lincoln Zoo School, Millbrook School, Minnesota Zoo School, Omaha's Henry Doorly Zoo's Zoo Academy, and Zoo Magnet Center. All of these models have a unique structure that provides various experiences based on the commitment and partnerships developed between the school districts and the zoos.

For example, the Omaha's Henry Doorly Zoo's Zoo Acad- 
emy - serving as the research academy for this study-is one example of an effective career academy model for science education. The academy has become an excellent work-based learning model and demonstrates how to successfully collaborate and form partnerships between school districts and informal science education organizations.

The zoo academy model is a prime example of science education reform in action. This program places both teachers and students into a non-traditional science-learning environment where all participants observe, learn, and apply scientific knowledge to real-world situations. The zoo academy becomes a safe environment where the teacher is given the opportunity to freely guide students through active scientific inquiry, establish a community-learning environment, and emphasize student understanding. The combination of these components leads to the establishment of a perfect learning environment for students to demonstrate their understanding of scientific concepts, and to freely investigate, to research, analyze, and communicate science explanations to peers and professionals. Selected zoo academy teachers spent three months interning at the zoo to develop current curriculum, develop conceptual connections between science, math, social studies, and English courses, and zoo business. Teachers strive to develop an understanding of conservation issues facing zoos and the community while establishing a working relationship with zoo employees. By fostering this small learning community goal, learning will take place in an atmosphere of adult cohesion and acceptance. Building this relationship with animal area supervisors and animal curators is a key component to assure the experiences the students receive are positive, educational, and relevant.

The academy teachers teaming up with the expertise of the zoo staff provides a very rich inquiry-based learning environment for students. The teachers plan the curriculum goals around inquiry problem-based experiences. In doing this, the teachers constantly evaluate their own knowledge and expertise, and determine where they need assistants to meet the needs of the students. The zoo staff becomes the resource needed to help the teacher guide the students through scientific investigations and experiences with zoo conservation scientists. This experience establishes a relationship between the students and zoo staff by giving everyone the opportunity to communicate their findings and discuss the impact of new discoveries and how it relates to current conservation issues.

The zoo academy model is a combination of three major educational components: career exploration, classroom experiences, and scientific research opportunities. Career exploration allows for students to freely explore their career goals through internships. The internships give students the opportunity to work directly with horticulturists, nutritionists, veterinarian staff, and animal management teams, giving the students a chance to discover new scientific careers and start the career decision process.

The zoo academy course work is developed to give students a variety of learning opportunities and daily experiences by taking advantage of access to zoo professionals, research laboratories, animal exhibits, and behind-the-scenes areas. All of these opportunities are used to establish a living laboratory setting. This concept of a living laboratory is very successful and important to the whole concept of the program. The interaction between the teachers and zoo staff allows for more opportunities to apply scientific concepts and to see real-world examples.

\section{Experiential Learning}

There are many terms to describe high school students' practical, hands-on learning experiences in sciences. School programs that emphasize practical experienced-based science curriculum are referred to as focus schools, schools-within-aschool, career academies, work-based experiences, and co-op learning programs (Breunlin et al., 2005; Conley, 2001; Kemple, 2004; Quint, 2006). However, all of these programs rely on a connected learning theory where students complete assignments that are hands-on, applied, and relevant (Breunlin et al., 2005; Conley, 2001; Hoachlander, 2008; Silverstein et al., 2009) and are thought to be of greater learning value than co-occurring traditional classroom activities. The goal of many programs that emphasize practical experienced-based connected science curriculum is to assist students in becoming good science consumers. From the students' perspective, these programs are dynamic, relevant, and not only popular, but successful.

Experiential learning instructional models centers students learning about real-world problems that can have multiple solutions (Hmelo-Silver, 2004; Visconti, 2010). Experiential curriculum is designed to have several integrated theme-based units for the students to develop the skills they need to complete real-world experiences in the community through projects and internships (Hmelo-Silver, 2004; Visconti, 2010). This approach to experiential learning helps students develop lifelong learning skills (Hmelo-Silver, 2004). Each curriculum framework leads to the same outcome - to create rigorous and relevant opportunities for students to apply their knowledge.

Experiential learning instruction can be called problem-based, challenge-based, or project-based learning. All three experiential learning styles are composed of the same basic framework including a big idea, essential questions, the challenge, solutions-action, and finally an assessment of outcomes (Johnson, Smith, Smythe, \& Varon, 2009). The process starts with a big idea of local or global importance. The teacher can come up with this big idea or work in collaboration with a community partner to find a relevant global idea that affects the workplace. The students proceed to research the big idea by bringing in the concepts and processes learned through course work that starts to strengthen the connections between what students are learning in the classroom and what they perceive to be the problem in the real world (Downing, Kwong, Chan, Lam, \& Downing, 2009; Johnson et al., 2009). Once the students develop an understanding of the scope of the big idea, they are challenged to solve the problem. At this point in time, the teacher becomes the facilitator and guides the students to work as a collaborative team. It is important for the students to have access to business partners and community members to work with professionals and gain the information and knowledge needed to complete the challenge. The final product and assessment is presented to the community involved in the problem. This community consists of the business partners, teachers, students, and community members (Johnson et al., 2009).

The experiential learning process provides opportunities for students to learn content and thinking strategies through the experience of solving real-world problems (Hmelo-Silver, 2004). Together, community leaders and educators work to provide the necessary guidance and experiences needed for the students to master the skills they need to become successful post high-school-educated citizenry (Hawkins et al., 2004). 


\section{Relevance, Rigor, and Relationships in Science and Math Programs}

The key to motivate and engage students in science and math programs is to establish a positive atmosphere for teachers to build student relationships and focus on taking rigorous curriculum and making it relevant. When students are engaged in the learning process, real achievement takes place and their chances to excel in the global world increases (Daggett, 2005). Evidence shows low-achieving students who are taking a combination of college prep courses filled with rigor, relevance, and good instruction leads to high student achievement (Conley, 2001; Toch et al., 2007). The students' ability to apply highrigor knowledge in relevant, real-world situations is the true assessment of achieving academic excellence (Daggett, 2005).

\section{Relevance}

Quality relevant learning experiences deepen the understanding and the connections students make between content knowledge gained in an academic setting and the knowledge needed to solve real-world problems (Conley, 2001; Daggett, 2005; Hugh et al., 2006; Hirsch, 2001). Engaging students in relevant community service projects, internships, and academy programs help students understand why the content learned in core classes is important (Conley, 2001; Hugh et al., 2006; Hoachlander, 2008). These students are able to make in-depth connections between the curriculum and relevant experience needed to become a scientifically literate community member. Students who are engaged in the learning process are less distracted and spend more time focused on the learning process that leads to active participation and academic success (Deutsch, 2003). The goal of many programs that emphasize experienced-based science curriculum is to assist students in becoming responsible and scientifically literate citizens. To achieve this goal, schools are increasing diversifying programs to expand new and interesting ways for students to explore their interest through the 11th-grade and 12th-grade years by collaborating with community organizations (Conley, 2001). Educators and organizations are sharing content information the students must learn and the opportunities that naturally occur in daily work routines. This joint collaboration helps students make the connections needed to dig deeper into the knowledge and skills they gained from their experiences (Hugh et al., 2006).

\section{Rigor}

Challenging rigorous curriculum that provides a balance in content breadth and depth in order for students to gain understanding and knowledge is necessary to create an environment of academic excellence (Daggett, 2005; Hirsch, 2001; Hoachlander, 2008; Mehan, 2006). The development of rigorous curriculum is very exacting and requires balancing the correct breadth and relevance of content areas to enter into a deep knowledge of the subject (Daggett, 2005; Hirsch, 2001). The best way to learn and build upon general principles is through multiple examples and hands-on experiences solving real-world problems (Hirsch, 2001). For example, the 11th-grade students entering the Zoo Academy are required to complete the following science courses: zoology, zoo orientation, and comparative anatomy to gain the knowledge and experiences needed to develop a deep understanding of life science concepts. These students take their learning process deeper by applying knowledge and prior experiences to real-world situations in animal management, one of many careers at the research Zoo Academy. By the 12th grade, students continue to build on and expand their breadth and depth of knowledge of life science content by applying content knowledge from multiple disciplines, math, English, and social studies, to the scientific process of developing and conducting a scientific research project. This rigorous scope and sequence of science courses is a nice balance between breadth, depth, and relevance of the science curriculum. The true indicator of academic excellence through rigorous curriculum is the ability of the students to apply what they learn in school to a variety of situations in the real world (Daggett, 2005; Hugh et al., 2006).

\section{Relationships}

Personalized relationships and a positive school climate where the students and adults are able to express care and concern for students' well-being, intellectual growth, and educational success (Cleary \& English, 2005; Dryer, 1996; McLeod \& Kilpatrick, 2001; Quint, 2006) is essential for creating a holistic environment where students are developing the basic knowledge, strong personal and interpersonal skills, and ability required to compete globally in the 21 st century (Mackin, 1996). Personalizing the school environment to establish positive relationships between students and teachers requires establishing personal adult advocates, personal learning plans, differentiated teaching, and the creation of small learning communities (Cleary \& English, 2005; Dryer, 1996). The development of the student-teacher relationship becomes apparent when instructional learning styles are incorporated into lesson plans. Research clearly shows it is important to organize lessons to meet the needs of various learning styles (Dryer, 1996; Mackin, 1996). From the students' perspective, the attitude towards students and presentation style are as important as class content (Dryer, 1996).

These findings demonstrate teachers must understand different student learning styles, build rapport, develop mutual respect, and effectively communicate in order to convey their subject matter (Dryer, 1996). It is believed that teachers should act as personal adult advocates serving in the role of supporting students academically, able to adapt and teach to all types of learning styles, deal with the social tribulations of adolescence, and assist students as needed (Cleary \& English, 2005; Cesswell $\&$ Rasmussen, 1996). Through the advice and direction of the teacher, the students will have individualized personal learning plans to make sure that their individual goals and expectations of high school are clearly defined and understood (Dryer, 1996); this is key to the motivational element in the learning process of adolescents (Quint, 2006). Establishing a learning environment where students feel trusted, respected, and encouraged leads to students learning how to think, try out ideas, express their views, interact in teams, and become part of a dynamic learning process within an environment (Cesswell \& Rasmussen, 1996; Mackin, 1996). Research shows that students in academies report high levels of interpersonal support and high expectations from teachers and peers (Breunlin et al., 2005; Kemple, 2004). Career academies provide students with explicit introductions to the world of work and furnish them with skills and connections to help them transition from high school to successful employment (Kemple, 2004). 


\section{Structure of Omaha’s Henry Doorly Zoo’s Zoo Academy}

In this study 11th- and 12th-grade students complete all of the core curricular courses required for graduation in the research project zoo academy. The zoo academy course work was developed to give students a variety of learning opportunities and daily experiences by taking advantage of access to zoo professionals, research laboratories, animal exhibits, and behind-the-scenes areas. All of these opportunities were used to establish a living laboratory setting. This concept of a living laboratory is very successful and important to the whole concept of the program. The interaction between the teachers and zoo staff allows for multiple opportunities to apply content knowledge to daily real-world situations.

The students followed a four-hour academic block schedule which had the flexibility for the teachers (science, math, English, and social studies) and students to work as a collaborative team and complete problem-based experiences throughout the school year including:

Science. Science coursework included: (a) Zoology, (b) Comparative Anatomy, (c) Honors Research, (d) Animal Externship, (e) Zoo Orientation, and (f) Horticulture.

Math. Math coursework included: (a) Algebra 1, (b) Algebra 2, (c) Honors Algebra 2, (d) Pre-Calculus, (e) Trigonometry, and (f) Geometry.

English. English coursework included: (a) English 11, (b) Honors English 11, (c) Contemporary Literature, and (d) Honors World Literature.

Social Studies. Social Studies coursework included: (a) Sociology, (b) Psychology, (c) US Foreign Relations, (d) American Government, (e) Honors American Government, and (f) Issues in Geography.

Courses were offered during a four-hour academic block A (Monday and Wednesday) and B (Tuesday and Thursday) schedule. Friday of each week was a service-learning day. The service-learning day was designed to give students the flexibility to continue their individual projects with zoo staff, make up classes missed during the week, work in teams on challengebased projects or work with science mentors on research projects. During the week, students were also pulled out of classes to participate in a variety of unique educational experiences that occur at the zoo on a daily basis including planning meetings for new exhibits, witnessing the birth of newborn animals, and participating in animal nutrition and feeding activities.

\section{Unique Learning Opportunities}

Theoretically, the flexibility to purposefully pull students out of classes for unique learning opportunities may result in prior knowledge through hands-on science experiences, deepening their understanding of the curriculum content even before its introduction later in class - thus outside of the traditional classroom learning promotes skills that simultaneously renew academic value (Hugh et al., 2006). Educators, community partners, and business leaders know we need to address the issue of better preparing our students for success if they are to become globally competitive on science and math examinations, successful in science classrooms, and competitive in tomorrow's science careers (Achieve, Inc., 2009). Science classroom communities of practice and science workplace communities of practice focused on the key elements of rigor, relevance, and relationships provide a key element in the equation for improved and sustained student success in the classroom and the development of a scientifically literate citizenry (Achieve, Inc., 2009).

\section{Methodology}

\section{Purpose of the Study}

The purpose of this study was to compare students' measured Likert scale perceptions of posttest school climate survey, relevance, rigor, and relationships domain scores following 11thand 12th-grade participation in either an integrated experiential zoo-based academic high school science program $(n=18)$ or a same school district control group integrated experiential schoolbased academic high school science program $(n=18)$.

\section{Student Participant Demographics}

The maximum accrual for this study was $(N=36)$ including a naturally formed group of 11 th-grade and 12th-grade students who participated in a zoo-based experiential academic high school science program $(n=18)$ and a randomly selected control group of 11th-grade and 12th-grade students who participated in a school-based experiential academic high school science program $(n=18)$. Students who attended the zoo-based experiential academic high school science program spent the school day at the zoo immersed in experiential science opportunities and academic course work for 11th-grade and 12thgrade school year. Students who attended the same school districts' school-based experiential academic high school science program spent the school day at their home high school immersed in experiential science opportunities and academic course work for 11th-grade and 12th-grade school year. ACT composite scores were equivalent for students participating in both science programs where zoo-based experiential academic high school science program students ACT, $M=20.83$, schoolbased experiential academic high school science program students ACT, $M=20.72$, and independent $t(34)=.08, p=.936$ (two-tailed), ns. Furthermore, science GPA composite scores were equivalent for students participating in both science programs where zoo-based experiential academic high school science program students science GPA, $M=3.25$, school-based experiential academic high school science program students science GPA, $M=3.27$, and independent $t(34)=-.12, p=.905$ (two-tailed), ns. The gender ratio of students participating in a zoo-based experiential academic high school science program was 6 males (33\%) and 12 females $(67 \%)$ and the gender ratio of students participating in a school-based experiential academic high school science program was 14 males (78\%) and 4 females $(22 \%)$. The age range for all study participants was from 16 years to 18 years. Finally, the ethnic and racial origin of students who participated in the zoo-based experiential academic high school science program was 18 Caucasian (100\%) while the ethnic and racial origin of students who participated in the school-based experiential academic high school science program was 16 Caucasian (89\%), 1 African American (5.5\%), and 1 Asian $(5.5 \%)$. The racial and ethnic origin of the study participants was congruent with the research school districts racial and ethnic demographics of 11th-grade and 12th-grade students. 


\section{Description of Procedures}

Research design. The posttest-only control-group comparative survey study design is displayed in the following notation:

$\begin{array}{llll}\text { Group } 1 & \mathrm{X}_{1} & \mathrm{Y}_{1} & \mathrm{O}_{1}\end{array}$

$\begin{array}{llll}\text { Group } 2 & \mathrm{X}_{1} & \mathrm{Y}_{2} & \mathrm{O}_{1}\end{array}$

Group 1 = study participants \#1. Naturally formed group of students $(n=18)$ completing the 11th-grade and 12th-grade.

Group 2 = study participants \#2. Randomly selected group of students $(n=18)$ completing the 11th-grade and 12th-grade.

$\mathbf{X}_{1}=$ study constant. All research study students $(N=36)$ were enrolled in the same public school district and completed the 11th-grade and 12th-grade school years science curriculum.

$Y_{1}=$ study independent variable, zoo-based science coursework delivery site, condition \#1. Experimental group students completed an integrated experiential zoo-based academic high school science program.

$\mathbf{Y}_{2}=$ study independent variable, school-based science coursework delivery site, condition \#2. Control group students completed an integrated experiential school-based academic high school science program.

$\mathbf{O}_{1}=$ study posttest dependent measures. Students' perceptions of end of program posttest relevance (28 items), rigor (14 items), and relationships (29 items) were measured using a five point Likert scale survey instrument- $1=$ Strongly Disagree, 2 = Disagree, 3 = Neutral, 4 = Agree, 5 = Strongly Agree-developed and validated by the participating research school district (Papillion-La Vista School District Student Climate Survey, 2009; Bernhardt, 2004; Easton, 2008). Sample survey relevance questions included: I have opportunities to choose my own projects; I understand how to apply what I learn at school to real-life situations; and doing well in school makes me feel good about myself. Sample survey rigor questions included: I feel challenged at this school; my teachers expect me to do my best; and the work at this school is challenging. Sample survey relationship questions included: I feel like I belong at this school; Teachers encourage me to assess the quality of my own work; and I am treated with respect by teachers.

\section{Research Questions}

The following research question and three sub-questions guided the study. Research Question \#1: Did experimental group students who completed an integrated experiential zoobased academic high school science program compared to control group students who completed an integrated experiential school-based academic high school science program have congruent or different Likert scale perceptions of school climate domains for: (a) relevance, (b) rigor, and (c) relationships?

Research sub-question 1a: Were posttest (a) relevance Likert scale school climate perceptions results congruent or different for students who completed a zoo-based academic high school experiential science program compared to students who completed a school-based academic high school experiential science program?

Research sub-question 1b: Were posttest (b) rigor Likert scale school climate perceptions results congruent or different for students who completed a zoo-based academic high school experiential science program compared to students who completed a school-based academic high school experiential science program?

Research sub-question 1c: Were posttest (c) relationships
Likert scale school climate perceptions results congruent or different for students who completed a zoo-based academic high school experiential science program compared to students who completed a school-based academic high school experiential science program?

\section{Assumptions and Limitations of the Study}

The design of this study had several strong features including a standard science curriculum developed by curriculum experts, teachers, and administrators to have equivalent rigor and relevance so only the science curriculum delivery sites, the zoo academy or the traditional high school, differ in this study. Students were matched for ACT composite scores and science grade point average scores. Furthermore, the research school district equally supported the zoo-based academic high school experiential science program and the school-based academic high school experiential science program financially and through teacher assignment. Finally, all students participating in the naturally formed zoo-school group and all students, randomly selected, for participation in the control group were required to be on track for graduation. Data on student perceptions were routinely collected at the end of the 2010, school year and included in the study. Study findings were limited to the students participating in the zoo-based academic high school experiential science program and the school-based academic high school experiential science program. The small sample size and newly developed academic program may limit the utility and generalizing of the study results and findings. Finally, participating school district and University of Nebraska Medical Center/University of Nebraska at Omaha Joint Institutional Review Board for the Protection of Human Subjects approval was granted for this study before data were analyzed.

\section{Results}

The purpose of this study was to compare students' measured Likert scale perceptions of posttest school climate survey, relevance, rigor, and relationships domains following 11 th- and 12th-grade participation in either an integrated experiential zoo-based academic high school science program $(n=18)$ or a same school district integrated experiential school-based academic high school science program $(n=18)$. Science coursework delivery site served as the study's independent variable. Research sub-question 1a results indicate that 11 th- and 12thgrade students who attended the integrated experiential zoobased academic high school science program had statistically greater posttest Likert scale school climate survey, mean perceived relevance domain scores $(M=4.16, S D=.35)$ compared to 11th- and 12th-grade students who attended the integrated experiential school-based academic high school science program posttest Likert scale school climate survey, mean perceived relevance domain scores $(M=3.54, S D=.53)$ where independent $t(34)=4.13, p=.0002$ (two-tailed), ES $=1.410$. Furthermore, research sub-question 1a results indicate that 11 th- and 12th-grade students who attended the integrated experiential zoo-based academic high school science program had statistically greater posttest Likert scale school climate survey, mean perceived rigor domain scores $(M=4.26, S D=.36)$ compared to 11 th- and 12th-grade students who attended the integrated experiential school-based academic high school science program posttest Likert scale school climate survey, mean perceived 
rigor domain scores $(M=3.72, S D=.51)$ where independent $t(34)=3.66, p=.0008$ (two-tailed), ES $=1.237$. Finally, research sub-question $1 \mathrm{c}$ results indicate that 11 th- and 12 thgrade students who attended the integrated experiential zoobased academic high school science program had statistically greater posttest Likert scale school climate survey, mean perceived relationships domain scores $(M=4.40, S D=.37)$ compared to 11 th- and 12th-grade students who attended the integrated experiential school-based academic high school science program posttest Likert scale school climate survey, mean perceived relevance domain scores $(M=3.61, S D=.56)$ where independent $t(34)=4.98, p<.0001$ (two-tailed), $\mathrm{ES}=1.690$.

\section{Conclusion}

Inspecting the overall, results indicated that students who completed the zoo-based academic high school experiential science program compared to students who completed the school-based academic high school experiential science program had statistically greater ending of school year Likert scale perceptions $(1=$ Strongly disagree; $2=$ Disagree; $3=$ Neutral; 4 $=$ Agree; and $5=$ Strongly Agree) of program relevance measured within the Agreed range where students in the schoolbased academic high school experiential science program had overall program relevance perceptions measured within the Neutral range. Based on this finding it may be asserted that students completing the zoo-based academic high school experiential science program believed that overall program relevance in their school setting was more apparent to them than to their peers who completed the school-based academic high school experiential science program. Furthermore, students who completed the zoo-based academic high school experiential science program compared to students who completed the school-based academic high school experiential science program had statistically greater ending of school year Likert scale perceptions of program rigor measured within the Agreed range where students in the school-based academic high school experiential science program had overall program rigor perceptions measured within the Neutral range. Based on this finding it may be asserted that students completing the zoo-based academic high school experiential science program believed that overall program rigor in their school setting was more apparent to them than to their peers who completed the school-based academic high school experiential science program. Finally, results indicated that students' who completed the zoo-based academic high school experiential science program compared to students' who completed the school-based academic high school experiential science program had statistically greater ending of school year Likert scale perceptions of program relationships measured within the Agreed range where students in the school-based academic high school experiential science program had overall program relationships perceptions measured within the Neutral range. Based on this finding it may also be asserted that students completing the zoo-based academic high school experiential science program believed that overall program relationships in their school setting was more apparent to them than to their peers who completed the school-based academic high school experiential science program.

\section{Discussion}

The students' overall perception of relevance, rigor and rela- tionships in their school setting was more apparent to the students who completed the Zoo-Based Academic High School Experiential Science Program than their peers who completed the School-Based Academic High School Experiential Science Program. The students' overall perception of relevance, rigor, and relationships in both learning environments sets these two academically equivalent programs apart giving the research school district more options to successfully prepare students to be competitive in today's global workforce. The average ranking of students in the United States on international math and science exams suggest that our students, while receiving a breadth of content knowledge, may not be receiving the depth of knowledge they need to be competitive in math and science careers (Bybee, 2010; Grigg et al., 2006; Mourshed et al., 2010; Sawchuk, 2010). Creating educational environments that have a balanced, rigorous curriculum, experiential learning in realworld science and math environments, while providing a sense of belonging is better preparing students to be competitive in today's global work force (Achieve, Inc., 2009; Kemple, 2004; Kemple \& Willner, 2008; Pittman, 2005). In order to establish positive learning environments and create a culture of learning; a school district must develop new content knowledge and skills, establish small learning communities, and have access to new resources (Dryer, 1996; Fullan, 2006; Manning \& Saddlemire, 1996; Sergiovanni, 1994). Effective science and math learning environments where teachers can freely guide students through experiential curriculum, supported by access to professional resources, and the establishment of alternative learning environments in the business community, empowers students to more freely explore careers and make a connection to their lives outside of school.

Educators, community partners, and business leaders know we need to address the issue of better preparing our students to be globally competitive on science and math examinations and success in the classroom, thus preparing them for the careers of tomorrow (Achieve, Inc., 2009; Wagner, 2010). The educational system must address the instructional needs of students while preparing them for work experiences of the future. Changes in both the classroom and the workplace are necessary in order to penetrate the barriers between classroom community of practice and the workplace community of practice (Hugh et al., 2006). To better prepare our students for success in the global economy innovative high school programs must be established to increase the number of students who graduate and successfully transition into postsecondary education or the global work force (Achieve, Inc., 2005; Jones, Yonezawa, Ballesteros, \& Mehan, 2002; Kemple, 2004; Kemple \& Willner, 2008; Quint, 2006). Educators have seen the impact and benefit of innovative high school programs, similar to Omaha's Henry Doorly Zoo's Zoo Academy, across the country decrease the number of students dropping out, improving school climate, strengthening curriculum and instruction, decreasing the achievement gap between majority and minority students, and preparing students for transition to postsecondary programs or employment after graduation (Kemple, 2004; Kemple \& Willner, 2008; Quint, 2006). Innovative high school programs must be established with the rigor to allow students to complete their core curricular courses during their freshman and sophomore years, opening up science and math electives and unique non-traditional education opportunities for students to explore a variety of career pathways during their junior and senior high school years (Achieve, Inc., 2005). 
Finally, if students can graduate from innovative high school programs, such as this study's zoo-based academic high school experiential science program, with strong math and science achievement and elevated perceptions of the relevance, rigor, and relationships inherent in their science studies we may hold out hope that these perceptions will motivate and inspire them to pursue university studies leading them on-as scientifically literate citizens - to tomorrow's absolutely essential scientific discoveries.

\section{REFERENCES}

Achieve, Inc. (2005). Rising to the challenge: Are high school graduates prepared for college and work? Washington DC: Peter D. Hart Research Associates.

Achieve, Inc. (2009). Taking root: Lesson learned for sustaining the college and career ready agenda. Washington DC: America Diploma Project Network.

Adelman, H., \& Taylor, L. (2009). Learning supports and small schools. Los Angeles, CA: School Mental Health Project, Department of Psychology, UCLA.

Bernhardt, V. (2004). Continuous improvement: It takes more than test scores. Leadership, 34, 16-19.

Breunlin, D. C., Mann, B. J., Kelly, D., Cimmarusti, R. A., Dunne, L., \& Lieber, C. (2005). Personalizing a large comprehensive high school. NASSP Bulletin, 89, 24-42. doi:10.1177/019263650508964503

Bybee, R. W. (2010). The teaching of science: 21st century perspectives. Arlington, VA: NSTA Press.

Cesswell, R. A., \& Rasmussen, P. (1996). Developing a structure for personalization in the high school. NASSP Bulletin, 80, 27-30. doi: $10.1177 / 019263659608058406$

Cleary, M., \& English, G. (2005). The small schools movement: Implications for health education. Journal of School Health, 75, 243.

Conley, D. T. (2001). Rethinking the senior year. NASSP Bulletin, 85, 26-41. doi:10.1177/019263650108562504

Daggett, W. R. (2005). Achieving academic excellence through rigor and relevance. Rexford, NY: International Center for Leadership in Education.

Deutsch, F. M. (2003). How small classes benefit high school students. NASSP Bulletin, 87, 35-44. doi:10.1177/019263650308763504

Downing, K., Kwong, T., Chan, S.-W., Lam, T.-F., \& Downing, W.-K. (2009). Problem-based learning and the development of metacognition. Higher Education, 57, 609-621. doi:10.1007/s10734-008-9165-x

Dryer, T. J. (1996). Personalization: If schools don't implement this one, there will be no reform. NASSP Bulletin, 80, 1-8. doi:10.1177/019263659608058402

Easton, L. (2008). Mix it up. Journal of Staff Development, 29, 21-24.

Elliott, M. N., Hanser, L. M., \& Gilroy, C. L. (2002). Career academies: Additional evidence of positive student outcomes. Journal of Education for Students Placed at Risk (JESPAR), 7, 71-90. doi:10.1207/S15327671ESPR0701 5

Fullan, M. (2006). Change theory: A force for school improvement. Center for Strategic Education, 157, 3-14.

Gonzales, P., Williams, T., Jocelyn, L., Roey, S., Kastberg, D., \& Brenwald, S. (2008). Highlights from TIMSS 2007: Mathematics and science achievement of US fourth and eighth-grade students in an international context. URL (last checked 9 December 2008). http//:www.nces.ed.gov

Graves, L. N. (1992). Cooperative learning communities: Context for a new vision of education and society. Journal of Education, 2, 57-79.

Grigg, W., Lauko, M. A., \& Brockway, D. M. (2006). Nation's report card: science 2005. Washington DC: National Center for Education Statistics.

Hawkins, J. D., Oesterle, S., \& Hill, K. G. (2004). Successful young adult development. Seattle, WA: The Bill \& Melinda Gates Foundation, Social Development Research Group, University of Washington.

Hirsch Jr., E. D. (2001). Seeking breadth and depth in the curriculum. Association for Supervision and Curriculum Development, 59, 22-25.
Hmelo-Silver, C. (2004). Problem-based learning: What and how do students learn? Educational Psychology Review, 16, 235-266. doi:10.1023/B:EDPR.0000034022.16470.f3

Hoachlander, G. (2008). Bringing industry to the classroom. Educational Leadership, 65, 22-27.

Hugh, M., Taylor, J., Chin, P., Hutchinson, N. L. (2006). Co-op students' access to shared knowledge in science-rich workplaces. Science Education, 91, 115-132.

Johnson, B., \& McElroy, T. M. (2010). The changing role of the teacher in the 21st century. Teachers.net Gazette, 7.

http://www.teachers.net/gazette

Johnson, L. F., Smith, R. S., Smythe, J. T., \& Varon, R. K. (2009). Challenge-based learning: An approach for our time. Austin, TX: The New Media Consortium.

Jones, M., Yonezawa, S., Ballesteros, E., \& Mehan, H. (2002). Shaping pathways to higher education. Educational Researcher, 31, 3-11. doi:10.3102/0013189X031002003A

Keefe, J. W., Kelly, E. A., \& Miller, S. K. (1985). School climate: Clear definitions and a model for a larger setting. NASSP Bulletin, 69, 70-77. doi:10.1177/019263658506948416

Kemple, J. J. (2004). Career academies: Impacts on labor market outcomes and educational attainment. New York: Manpower Demonstration Research Corporation.

Kemple, J. J., \& Willner, C. J. (2008). Career academies: Long-term impacts on labor market outcomes and educational attainment, and transitions to adulthood. New York: Manpower Demonstration Research Corporation.

Mackin, R. A. (1996). Hey, Dr. Bob, can we talk? Toward the creation of a personalized high school. NASSP Bulletin, 80, 9-16. doi: $10.1177 / 019263659608058403$

Manning, M. L., \& Saddlemire, R. (1996). Developing a sense of community in secondary schools. NASSP Bulletin, 80, 41-48. doi: $10.1177 / 019263659608058409$

McLeod, J., \& Kilpatrick, K. (2001). Exploring science at the museum. Educational Leadership, 58, 59-63.

Mehan, H. (2006). Restructuring and reculturing schools to provide students with multiple pathways to college and career. San Diego, CA: University of California.

Mourshed, M., Chijioke, C., \& Barber, M. (2010). How the world's most improved school systems keep getting better. London: McKinsey \& Company.

National Academies (2007). Rising above the gathering storm: Energizing and employing America for a brighter economic future. http://www.nap.edu/catalog/11463.html

National Center for Education Statistics (2011a). Comparing TIMSS with NAEP and PISA in mathematics and science. Washington DC: US Department of Education, Institute of Education Sciences.

National Center for Education Statistics (2011b). The nation's report card: Mathematics 2009. (NCES 2010-451). Washington DC: US Department of Education, Institute of Education Sciences.

National Center for Education Statistics (2011c). The nation's report card: Science 2009. (NCES 2011-451). Washington DC: US Department of Education, Institute of Education Sciences.

National Research Council (NRC) (1996). National science education standards. Washington DC: National Academies Press.

National Association of Secondary School Principals (2005). Breaking ranks II: An executive summary.

http://www.nwrel.org/scpd/sslc/institutes_2005/documents/Ollarvia_ executive-summary.pdf

Peterson, P.E. (2010). US students advancing in math trails most industrialized nations. http://www.physorg.com

Pittman, K. (2005). Blurring the lines for learning: Youth and community centered responses to the challenges of high school reform. Louisville, KY: CCSSO Summer Institute.

Quint, J. (2006). Meeting five critical challenges of high school reform. New York: Manpower Demonstration Research Corporation.

Quint, J. (2008). Implementation study of smaller learning communities: Final report. US Department of Education.

http://www.edpubs.org

Quint, J. (2008). Lessons from leading models. Educational Leadership, 65, 64-68. 


\section{E. A. MULKERRIN, J. W. HILL}

Sawchuk, S. (2010). Global study tracks common paths to improving schooling. Education Week, 30, 10.

Senge, P., Cambron-McCabe, N., Lucas, T., Smith, B., Dutton, J., \& Kleiner, A. (2000). Schools that learn. New York: Doubleday Dell Publishing Group, Inc.

Sergiovanni, T. J. (1994). Organizations or communities? Changing the metaphor changes the theory. Educational Administration Quarterly, 30, 214-226. doi:10.1177/0013161X94030002007

Silverstein, S. S., Dubner, J., Miller, J., Glied, S., \& Loike, J. D. (2009). Teachers' participation in research programs improves their students' achievement in science. Science, 326, 440-442.

doi:10.1126/science. 1177344
Smith, T. J. (2008). Striking the balance: Career academies combine academic rigor and workplace relevance. National High School Center, Washington DC: American Institutes for Research. http://www.betterhighschools.org

Toch, T., Jerald, C. D., \& Dillon, E. (2007). Surprise: High school reform is working. Phi Delta Kappan, 88, 433-437.

Visconti, C. F. (2010). Problem-based learning: Teaching skills for evidence-based practice. Perspectives on Issues in Higher Education, 13, 27-31. doi:10.1044/ihe13.1.27

Wagner, T. (2010). The global achievement gap: Why even our best schools don't teach the new survival skills our children need and what we can do about it. New York: Perseus Books Group. 